\title{
ADUBAÇÃO NITROGENADA EM COBERTURA PARA A CULTURA DO FEIJOEIRO EM SISTEMA DE PLANTIO DIRETO NA PALHA
}

\author{
COVER NITROGEN FERTILIZATION ON THE COMMON BEAN \\ IN NO-TILLAGE SYSTEM
}

\author{
Sérgio Roberto PIASKOWSKI \\ Orientador: Professor Dr. Pedro RONZELLI JÚNIOR \\ Departamento de Fitotecnia e Fitossanitarismo
}

\begin{abstract}
RESUMO
Nos anos agrícolas de 1996/97 e 1997/98 foram conduzidos experimentos, em campo, na Fazenda Escola da Universidade Estadual de Ponta Grossa e na Fazenda do Colégio Agrícola de Palmeira, respectivamente, ambas com histórico de oito anos de plantio direto na palha, com o objetivo de estudar a adubação nitrogenada para a cultura do feijoeiro semeado no sistema de plantio direto na palha, avaliando o rendimento, seus componentes, as modificações morfológicas na planta e a matéria seca. O delineamento experimental utilizado foi o de blocos ao acaso, com seis tratamentos $(0,20$, 40, 60, 80 e $100 \mathrm{~kg}$ de N.ha-1) e cinco repetições, utilizando-se como indicadora a variedade ' $F T$ Nobre'. As parcelas experimentais tinham seis linhas de 6,00 m espaçadas de 0,45 m, no experimento conduzido em Ponta Grossa, e seis linhas espaçadas de 0,40 m no experimento conduzido em Palmeira. Foram separadas duas linhas com área útil de $4,50 \mathrm{~m}^{2}$ para 0 experimento conduzido em Ponta Grossa, e $4,80 \mathrm{~m}^{2}$ para 0

conduzido em Palmeira, com a finalidade de avaliar o rendimento. Em fileiras extraordinárias foram coletadas dez plantas, nos estádios de $V_{2}$ a $R_{9}$, onde no experimento conduzido em Ponta Grossa foi avaliada a matéria seca nos estádios $V_{2}$ a $R_{8}$ e no $R_{9}$, além desta, as características morfológicas, componentes de rendimento e rendimento. No experimento de Palmeira nos estádios $\mathrm{V}_{2}$ a $\mathrm{R}_{8}$, matéria seca, características morfológicas e no estádio $R_{9}$, além das já descritas, componentes de rendimento e rendimento. No experimento conduzido em Ponta Grossa, a melhor resposta foi para a dose de $100 \mathrm{~kg}$ de N.ha-1 com produtividade de $2.207 \mathrm{~kg} \cdot$ ha $^{-1} \mathrm{e}$ a pior com $1.614 \mathrm{~kg} \cdot \mathrm{ha}^{-1}$ na parcela testemunha enquanto que no conduzido em Palmeira, a melhor resposta ocorreu para a dose de $40 \mathrm{~kg} \cdot \mathrm{ha}^{-1}$ de nitrogênio com $2.230 \mathrm{~kg} \cdot \mathrm{ha}^{-1}$ e a pior com $1.808 \mathrm{~kg} \cdot \mathrm{ha}^{-1}$ na dose de $20 \mathrm{~kg} \cdot \mathrm{ha}^{-1}$. Em ambos os experimentos não houve diferença estatística entre o melhor tratamento e a testemunha.
\end{abstract}

\section{ABSTRACT}

Field trials were carried out in the agricultural years of 1996/97 and 1997/98 at the State University of Ponta Grossa School and at the Agricultural High School Farm of Palmeira, respectively, both of them under no-tillage system for eight years, with the aim of study nitrogen fertilization for bean culture under no-tillage system. Yield, their components, plant morphological rnodifications and dry matter were evaluated. The experimental design employed was a randomized complete block, six treatments $\left(0,20,40,60,80\right.$ and $\left.100 \mathrm{~kg} \cdot \mathrm{ha}^{-1}\right)$ and five replications with me 'FT Nobre' as indicator variety. The experimental plots were six limes with $6,00 \mathrm{~m}$ each and $0,45 \mathrm{~m}$ among them, in the trial carried out at Ponta Grossa, and 0,40 m among the lines in the trial carried out at Palmeira. Two lines were left out, leaving with a usable area of $4,50 \mathrm{~m}^{2}$ and $4,80 \mathrm{~m}^{2}$ for the experiments carried out at Ponta Grossa and Palmeira, respectively, to evaluate the yield. Ten plants were harvested to evaluate dry matter during the $V_{2}$ to $R_{8}$ stages. In addition to dry matter, morphological characteristics, yield and their components were evaluated at the $R_{4}$ stage. At Palmeira evaluated dry matter and morphological characteristics were evaluated from $V_{2}$ to $R_{8}$ stages, to $R_{9}$ stage in addition these evaluations yield and their components were evaluated too. The best result was obtained at the higher nitrogen dosis $100 \mathrm{kgha}^{-1}$ and its production was $2.207 \mathrm{~kg} \cdot \mathrm{ha}^{-1}$ and the worst result was $1.614 \mathrm{~kg} \cdot \mathrm{ha}^{-1}$ at Ponta Grossa's trial. 